\title{
ICE IN CAVES AND ITS EFFECT ON THERMAL INVERSION AND PERMAFROST IN THE CASE OF THE VELIKA LEDENA JAMA V PARADANI, SMREKOVA DRAGA AND NEIGHBOURING DOLINES
}

\author{
LED V JAMAH IN NJEGOV VPLIV NA TOPLOTNI OBRAT \\ TER PERMAFROST NA PRIMERU VELIKE LEDENE JAME V \\ PARADANI, SMREKOVE DRAGE IN SOSEDNJIH VRTAČ
}

\author{
Andrej MIHEVC
}

\begin{abstract}
UDC 551.324.296:551.345(497.473Trnovski gozd) 551.584.6:551.324.296(497.473Trnovski gozd)

Andrej Mihevc: Ice in caves and its effect on thermal inversion and permafrost in the case of the Velika ledena jama $v$ Paradani, Smrekova draga and neighbouring dolines

In the Velika ledena jama v Paradani, in the karstic blowholes on the slopes of Smrekova draga and in the nearby dolines I measured and interpreted air temperatures and the effect of the summer outflow of cold air from them into the surrounding area. In winter, cold air enters the cave, radically cooling the entrance part of the cave, where for this reason there is permanent cave ice. The summertime circulation is reversed: emerging from the inner part of cave, which has an average temperature of around $4^{\circ} \mathrm{C}$, is air which only when it transits through the sub-cooled entrance part is then cooled to around $1^{\circ} \mathrm{C}$. This air comes to the surface and in the hollow at the cave entrance maintains a distinct thermal inversion during the warm part of the year. There is a similar air circulation and similar development of annual temperatures observed at the vents, where cave air emerges through rubble spread over cave entrances on slopes or at the bottom of dolines. The stable summer air temperatures of around $1^{\circ} \mathrm{C}$ in the vents where I conducted measurements indicate that underneath them there is also permafrost or sub-cooled rock and permanent ice. This is created and preserved, just like in the caves, due to the advection of cold air in winter. In Trnovski gozd, such karstic permafrost is found at an altitude of $1,100 \mathrm{~m}$ above sea level. The outflow of cold air from the vents in the summer, just like inside the cave, causes a distinct thermal inversion in dolines on the surface.

Keywords: karst, ice cave, blowholes, doline, cave climate, topoclimate, permafrost, thermal inversion.
\end{abstract}

Izvleček UDK 551.324.296:551.345(497.473Trnovski gozd) 551.584.6:551.324.296(497.473Trnovski gozd) Andrej Mihevc: Led v jamah in njegov vpliv na toplotni obrat ter permafrost na primeru Velike ledene jame v Paradani, Smrekove drage in sosednjih vrtač

V Veliki ledeni jami v Paradani, v dihalnikih na pobočjih Smrekove drage in v bližnjih vrtačah sem meril in interpretiral temperature zraka ter vpliv poletnega iztekanja hladnega zraka iz njih v okolico. V jamo pozimi vstopa mrzel zrak, ki močno podhladi vhodni del jame, kjer se zato ohranja stalni jamski led. Poletna cirkulacija je obrnjena; iz notranjega dela jame, ki ima povprečno temperaturo okrog $4^{\circ} \mathrm{C}$ piha zrak, ki se šele ob prehodu skozi podhlajeni vhodni del jame ohladi na okrog $1^{\circ} \mathrm{C}$. Ta zrak izhaja na površje in v kotanji pri vhodu v jamo vzdržuje $\mathrm{v}$ topli polovici leta izrazit toplotni obrat. Podobno zračno cirkulacijo in podoben potek letne temperature imajo tudi dihalniki, kjer jamski zrak izhaja skozi grušč, ki je zasul jamske vhode na pobočjih ali v dnu vrtač. Stabilne poletne temperature zraka okrog $1^{\circ} \mathrm{C} v$ dihalnikih, $\mathrm{v}$ katerih sem opravil meritve kažejo, da tudi pod njimi obstaja permafrost oziroma podhlajena kamnina in stalni led. Ta nastane in se ohranja, enako kot $\mathrm{v}$ jamah, zaradi advekcije mrzlega zraka pozimi. Na Trnovskem gozdu je tak kraški permafrost v nadmorski višini okrog 1100 $\mathrm{m}$. Iztekanje hladnega zraka iz dihalnikov povzroča poleti prav tako kot pri jami, izrazit toplotni obrat $\mathrm{v}$ kotanjah in na površju. Ključne besede: kras, ledena jama, dihalnik, vrtača, jamska klima, topoklima, permafrost, toplotni obrat.

${ }^{1}$ Karst Research Institute ZRC SAZU, Titov trg 2, SL-6230 Postojna, Slovenia, E-mail: Mihevc@zrc-sazu.si 


\section{INTRODUCTION}

The central part of Trnovski gozd is an extensive karstic plateau at an altitude of around 1,250 m. Rising above this surface is the pronounced Golak mountain chain (M. Golak 1,495 m). On the plateau and pass of Paradana, which separates the Golak mountains in the northwest from Mt. Bukovec $(1,445 \mathrm{~m})$, there are numerous dolines and large dolines or depressions, among which the largest are Smrekova draga and Mala Lazna. There are also several ice caves here, among which the best known is the Velika ledena jama v Paradani (Large Ice Cave at Paradana, hereinafter referred to simply as Paradana).

Karstic massifs such as Trnovski gozd are laced with karstic interconnected cavities of varying dimensions (Maire, 1990). Meteoric water flows through this system of cavities towards springs, and air also circulates through it. The air moves due to differences in pressure, and these differences depend to a large extent on the den- sity or temperature of the air. Microclimatic characteristics of the system can be observed more closely only in human-accessible caves, since the major portion of the cavities are impassable for humans and thereby inaccessible.

The air temperature in cavities in a karstic massif is fairly stable and is approximately the same as the average annual temperature of the air on the surface (Ford \& Williams, 1986; Badino, 1995). But since the outside temperature changes with the seasons, this brings about differences between the temperature and density of the air inside the massif and in the atmosphere. For this reason, and since the entrances to underground areas are at different altitudes, strong air currents appear in passages and shafts and at cave entrances.

In winter the cave air is warmer than the outside air, and emerges through the upper entrances. This phenom-

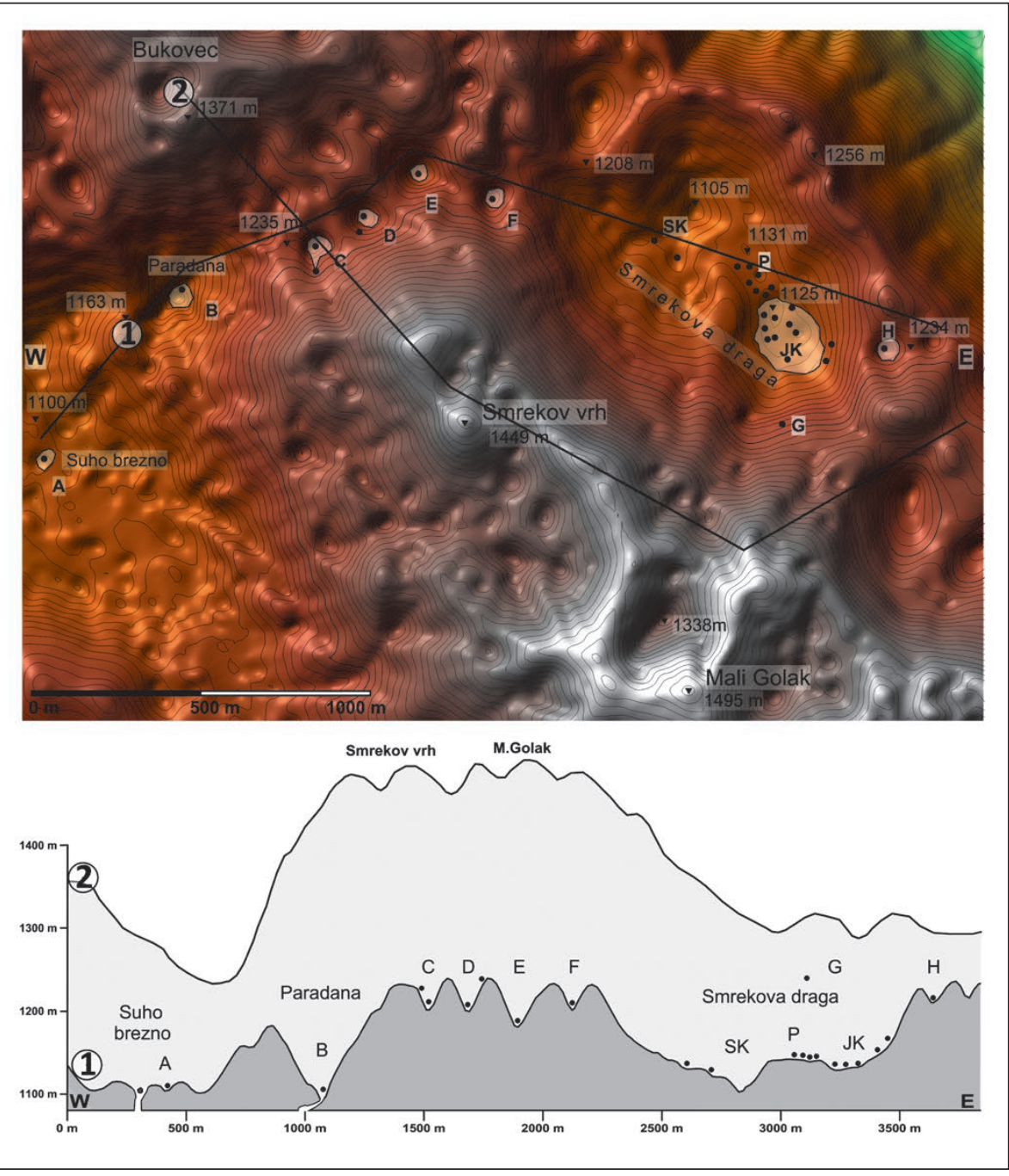

Figure 1: Digital elevation model and schematic cross section of the area under study. Letters indicate the measuring locations in dolines or at cave entrances. $\boldsymbol{G}$ - Cave by the road above Smrekova draga. SK - North depression, $\boldsymbol{P}$ - pass, JK - south depression. At the bottom of the dolines, by Paradana and at Smrekova draga, the areas indicated show pronounced vegetation inversion, an effect conditional on the air circulation from the caves and on the phenomenon of permafrost. Black lines indicate approximate lines of both profiles. 
enon is called the chimney effect in the professional literature (Leutcher, 2005; Badino, 1995). At the same time colder outside air flows into the karstic massif through the lower entrances.

In the warm half of the year, since the entrances to the system of karstic cavities are at different altitudes, colder and denser air flows out from the system through the lower cave entrances, while warmer and less dense outside air flows into the karstic massif through the higher entrances. Due to the temperature differences in accessible caves we have observed air flows through cave passages, and strong breezes at the entrances.

Caves and fissures in the ground through which there is strong air flow are called vents. The entrance parts of the cave system and the surrounding rock, where cold air enters the underground areas in winter, cool down to such an extent that this enables the formation and preservation of permanent cave ice. Paradana and the vents at Smrekova draga and in neighbouring dolines are just such lower entrances to the system.
In this article I wish to point out:

1. that the existence of permanent ice at Paradana and its preservation is a consequence of the particular air circulation in the entire karstic massif, and not just a consequence of local surface climatic or topographic conditions;

2. that the outflow of cold air from the system of karstic cavities to the surface on the slopes or at the bottom of karstic depressions in the summer, especially in the afternoon, close to the entrances or vents, has a powerful influence on the topoclimate and causes locally limited occurrences of pronounced temperature inversion in the ground-level layer of air, along with vegetation anomalies, where the size and shape of the depressions are of secondary importance;

3. that the draft from caves or vents with a constant temperature close to freezing point indicates the existence of areas of local permafrost.

\section{RESEARCH TO DATE}

In investigation of caves on the karstic plateau, at the entrance to Paradana and at nearby Smrekova draga, Karl Moser observed a thermal and vegetation inversion (Moser, 1889). He ascribed this to the location at the bottom of a karstic depression, where denser cold air was retained. The thermal inversion was supposedly also the reason for the generation and preservation of ice in the cave. Both locations were then described as textbook examples of the phenomenon of thermal and vegetation inversion. Later they were researched and described in detail in botanical terms as cold-air pools (Beck, 1906; Martinčič, 1977; Zupančič, 1980).

The phenomenon of ice in caves where the average year-round temperature is above freezing was explained as a consequence of air circulation by Fugger (1884). Similar explanations for the phenomenon of permanent ice in caves were given by Kraus (1894) and Balch (1900), and as part of a study of cave climate by Badino (1995). Luetscher (2005) also wrote about this in a special monograph on ice in caves.

Ice caves with moderate widths and below the snow line were described as a special kind of incomplete permafrost by Harris (1982), and a similar phenomenon of permafrost tied to the powerful circulation of air and the annual reversal of the direction of circulation, which arises on rubble slopes, was described by Delaloye (2003) and Morard (Morard, et al. 2008; Morard, 2011).
Moser (1889), who first described and measured the temperature in the Velika ledena jama $v$ Paradani and Mala ledena jama $v$ Paradani (=Small Ice Cave at Paradana) and in other ice caves in the surrounding area, along with other researchers (Beck, 1906; Michler, 1950; Kunaver, 1949; Habič, 1968), emphasised as the reason for the appearance and preservation of ice in particular the position at the bottom of a doline, the pocket-like shape of the cave, the shady position, the high level of forest vegetation around the entrance and snow avalanches.

More detailed botanical research (Hribar, 1960; Martinčič, 1977) showed, however, that the inversion occurs at Smrekova draga mainly in summer, and that the distribution of the thermal inversion and vegetation groupings within it are irregular, depending primarily on the "penetration of cold air" from the ground moraine or hillside rubble cooled in winter (Zupančič, 1980), or on the distribution of cold rubble strewn ground (Martinčič, 1998).

Paradana was described as a special climatic type of doline where cold air flows out of the caves by Gams (1972). Based on measurements of temperature and the movement of air in the deeper parts of the cave, the creation and preservation of ice in the cave was later ascribed to air circulation (Mihevc \& Gams, 1979; Mihevc, 1993; Nagode, 2002). 


\section{METHODS}

The greatest amount of data on the temperature conditions of the karstic underground in Trnovski gozd has been measured at Paradana. I used data from the literature (Mihevc \& Gams, 1979; Nagode, 2002) and data I collected through occasional measurements of temperature and air movement from 1978 on. From 2008 to 2012 I also placed dataloggers and measured the temperature on the surface above the cave, in the entrance funnel and $30 \mathrm{~m}$ deep within the cave.

I measured the temperature using DS1922L iButton $^{\bowtie}$ temperature loggers with a resolution of $0.1^{\circ} \mathrm{C}$. I experienced great difficulty here due to the loss of data through breakdowns of the recorders, perhaps because of lightning strikes. I measured air temperatures always in fine weather, and I also placed some temperature loggers.

I measured $\mathrm{CO}_{2}$ concentrations using a Vaisala
GM70 instrument, and the speed of air drafts using a manual Kestrel 4500 anemometer.

I inspected the depression of Smrekova draga and within it, for the requirements of measuring, I selected 24 of the more powerful vents from which cold air blew in the summer. At three of these I placed thermometers at a depth of around $40 \mathrm{~cm}$ below the surface. Since the annual temperature ranges at these were similar, I continued measurements and just one. At Smrekova draga I also placed a thermometer at the perimeter of the depression and at the lowest point. I also placed thermometers at two dolines between Smrekova draga and Paradana. At Paradana I measured the temperature with measurement intervals at depths of $100 \mathrm{~m}, 550 \mathrm{~m}$ and $700 \mathrm{~m}$.

Furthermore, from May to September 2012, once a month at all the stated locations I measured the temperature, wind speed in the vents and concentration of $\mathrm{CO}_{2}$.

\section{RESULTS AND INTERPRETATION OF MEASUREMENTS}

\section{VELIKA LEDENA JAMA V PARADANI}

Paradana is a cave $858 \mathrm{~m}$ deep and $6,534 \mathrm{~m}$ long. The entrance to the cave lies at the bottom of a large funnelshaped depression at an altitude of 1,130 m (Erker, 2014), in which there is a pronounced thermal inversion that is also reflected in the vegetation. In the lower part there is only moss growing on the rocks, then on the slope above there is grass, bushes, rhododendrons and dwarf willows, which transition into a spruce forest.

The major portion of the cave comprises vadose shafts. The majority of them were created in the area fault zone; the largest number of them are over a hundred metres deep. At depths below $700 \mathrm{~m}$ the shafts end out into a network of horizontal tunnels.

There is permanent ice in the entrance area of the cave. The quantity of ice has been estimated at several thousand cubic metres. It is impossible to determine the exact quantity, since it completely fills the galleries and shafts. Its quantity changes from year to year.

In the cold half of the year, when the outside temperature drops below around $4^{\circ} \mathrm{C}$, the cave starts sucking in air. The results of all the measurements have shown that the air in the cave becomes warmer the deeper it is. The air on 27 March 1989 (Nagode, 2002), with an outside temperature of $-1.6^{\circ} \mathrm{C}$, warmed up to around $0^{\circ} \mathrm{C}$ at a depth of $140 \mathrm{~m}$, to $1.1^{\circ} \mathrm{C}$ at a depth of $180 \mathrm{~m}$, to $1.5^{\circ} \mathrm{C}$ at a depth of $240 \mathrm{~m}$, to $3^{\circ} \mathrm{C}$ at a depth of $380 \mathrm{~m}$ and to $4.4^{\circ}$
$\mathrm{C}$ at a depth of $650 \mathrm{~m}$. In parallel shafts the depth growth in temperature was similar.

Measurements of the speed of air movement have shown that the draft in the cave is stronger if the outside temperature is lower. The speed of air entering the cave in winter reaches up to $2 \mathrm{~ms}^{-1}$ in a tunnel with a profile of around $4 \mathrm{~m}^{2}$. Yet since several parallel shafts and passages lead into the cave, along with numerous impassable squeezeswhich cannot be included in the observations, I estimate the air flow at such temperature to be approximately $16 \mathrm{~m}^{3} \mathrm{~s}^{-1}$.

The air that flows into the cave then flows off in unknown directions. A smaller portion may flow off into the lower but quite distant Vipava Valley, but the majority of the air probably flows off into the system of linked cavities in the Golak range, which act as chimneys. Air from the system exits on the surface at altitudes of around $1,400 \mathrm{~m}$. At such places we have observed in winter melted snow, since air flows out of the massif with a temperature above freezing. Since the entrance to Paradana lies at an altitude of $1,130 \mathrm{~m}$, there is an altitude difference within the cave system of around $300 \mathrm{~m}$, which facilitates strong air circulation.

When the outside temperature rises above the temperature of the massif and of the air in the cave system in the warm half of the year, the air flow reverses. In such conditions I found that the air flow is directed along the 
shafts upwards and then out of the cave. In August 2013 the air at a depth of $680 \mathrm{~m}$ was $3.9^{\circ} \mathrm{C}$, at a depth of 250 $\mathrm{m}$ it was $2.2^{\circ} \mathrm{C}$ and around the ice, at a depth of $110 \mathrm{~m}$, it was $1.1^{\circ} \mathrm{C}$. At $30 \mathrm{~m}$ deep, measured half a metre above the ice, the air temperature was $1^{\circ} \mathrm{C}$. Through the entrance and into the surrounding area, air was estimated to flow at around $10 \mathrm{~m}^{3}$ per second. In the entrance funnel at Paradana the cold air flowing out of the cave main-
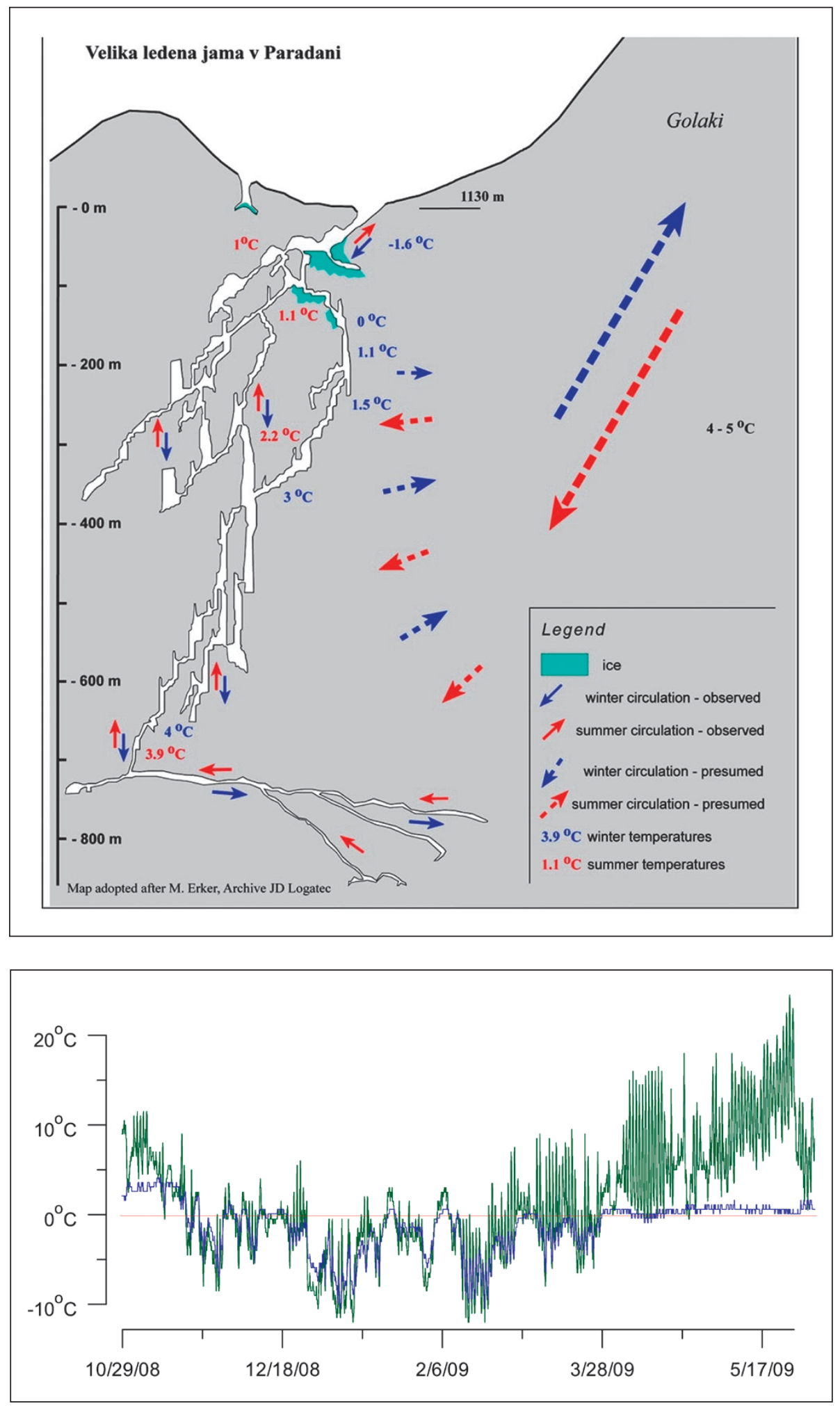

Figure 2: Schematic cross section of the Velika ledena jama $v$ Paradani. The summer and winter directions of air flow in the cave are indicated. This enables the creation and preservation of underground cave ice or permafrost.

Figure 3: Comparison of temperature development in the Velika ledena jama $v$ Paradani (Paradana) at a depth of around $30 \mathrm{~m}$ (blue) and on the surface above the cave (green) between October 2008 and June 2009. The temperature in the cave falls below $0^{\circ} \mathrm{C}$ due to the intrusion of cold air into the cave. When the outside temperature rises above around $4^{\circ} \mathrm{C}$, the direction of the draft reverses and starts blowing out of the cave. Air flows from the cave system, where the temperature is around $4^{\circ} \mathrm{C}$, but as it transits past the underground ice the air cools down to around $1^{\circ} \mathrm{C}$. 
tains a constant pool of cold air, which in the upper layer mixes with the outside air. In this air the concentration of $\mathrm{CO}_{2}$ is 460-520 ppM, while outside of it, in the open air at a height of $2.5 \mathrm{~m}$ from the ground, it is 320-360 ppM.

The annual range of temperatures in the eastern part of Paradana also indicate the two temperature regimes and direction of air flow. In the cold half of the year the temperature at these points often varies, reflecting the outside temperature. In the summer, when there is a prevalent outflow of air from the interior of the cave towards the surface, the temperature is low but very stable. Between these two regimes there are transitional periods with numerous short-lived variations.

\section{SMREKOVA DRAGA}

Smrekova draga is a $1,200 \mathrm{~m}$ long, $800 \mathrm{~m}$ wide and over $100 \mathrm{~m}$ deep depression composed of two large dolines. The lowest bottom level is in the northern doline $(1,105$ $\mathrm{m})$, the pass between the dolines is at an altitude of around $1,130 \mathrm{~m}$, and the bottom of the southern doline is at an altitude of $1,125 \mathrm{~m}$. Part of the bottom and part of the side slopes are composed of hillside or moraine material. The bottom of the southern doline is almost completely covered in bushes, while the northern doline, although it is deeper, is covered in spruces, and in places also mixed forest. The pass between the dolines is overgrown with old spruce forest. The ground on the pass is overgrown with a layer of moss and undegraded organic material up to $0.5 \mathrm{~m}$ thick, on which blueberries thrive.

The temperature measurements on the eastern perimeter of Smrekova draga and at the lowest point of the doline floor point to the same annual range of temperatures, with expected long thermal inversions in the cold half and night-time thermal inversions in the warm half of the year. These can be ascribed to the karstic doline.

The measurements at the vents, however, showed a different temperature range. In the summer of 2012 I measured the air temperatures in the vents of the southern doline, on the pass between the dolines and in the vents in the southern part of the northern doline. I measured the temperatures only in summer because in winter the vents are covered in snow and are inaccessible. I also placed a temperature logger in one of them.

In the northern doline I took measurements at two vents. Both are shallow, up to $1.5 \mathrm{~m}$ deep elongated dolines, at the bottom of which are rocks mingled with soil. In the summer, between the rocks cold air blew from the ground $\left(0,9 \mathrm{~ms}^{-1}\right)$, with a temperature of $3^{\circ} \mathrm{C}$. At a height of around $0.5 \mathrm{~m}$ from the ground the temperature was already around $10^{\circ} \mathrm{C}$, and $2.5 \mathrm{~m}$ from the ground it was around $20^{\circ} \mathrm{C}$.

There are 14 vents on the pass between the dolines. Most of them are shallow hollows up to $2 \mathrm{~m}$ deep. There is a draft between the rocks in them in various places, but I only measured the temperatures and air speed where the draft was strongest. The common characteristics were as follows: the summer temperature of the air bowing from the ground was between 0.7 and $3.7^{\circ} \mathrm{C}$ (Fig. 5), and its speed was between 0.1 and $1.8 \mathrm{~ms}^{-1}$. Both temperature and air speed depend to a great extent on the form and size of the channels between the rocks, and probably also on the degree to which the cold air mixes with the outside warmer air even between the rocks on the ground. I estimate that cold air was flowing out of the ground at a rate of around $2 \mathrm{~m}^{3} \mathrm{~s}^{-1}$. Here the summer temperature at a height of around $0.5 \mathrm{~m}$ above the vents was already around $10^{\circ} \mathrm{C}$, and at a height of $2.5 \mathrm{~m}$ above the ground

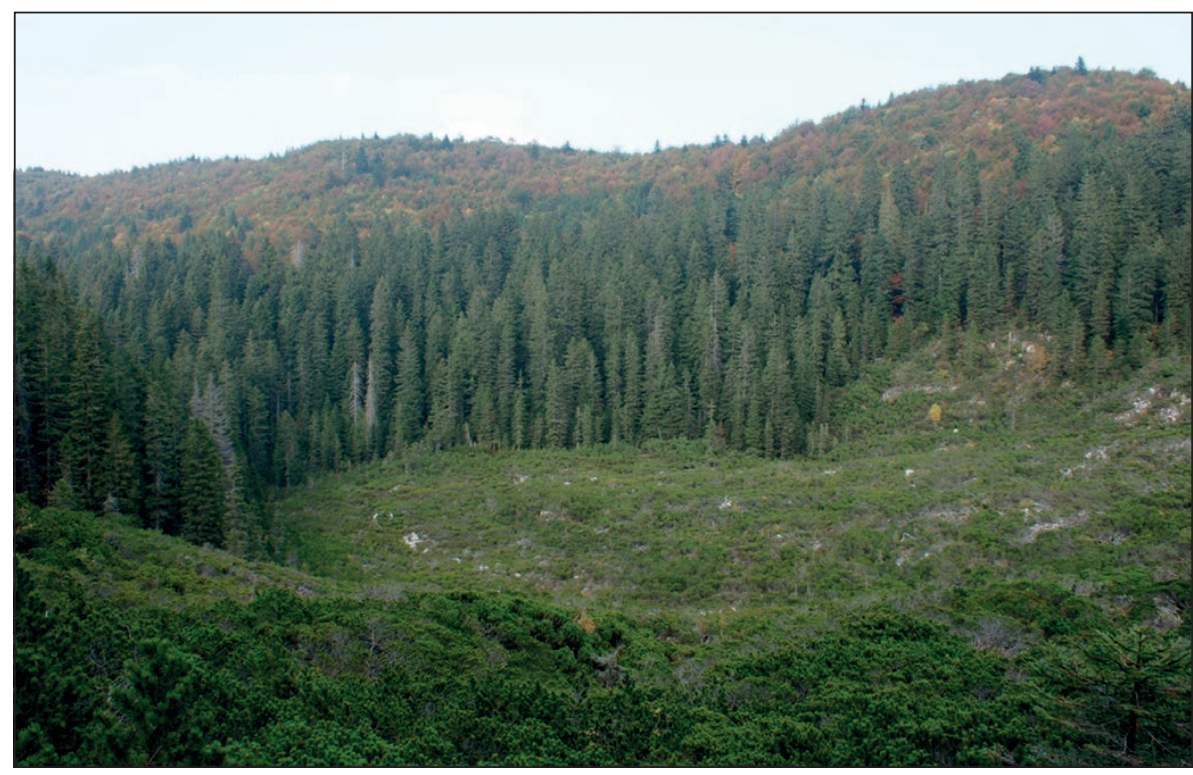

Figure 4: Vegetation inversion in Smrekova draga, view to the north. Beech grows along the perimeter, spruce below, and dwarf pine at the bottom of the depression. The vegetation inversion is a consequence of cold air inflow from blowholes at the bottom of the depression. 


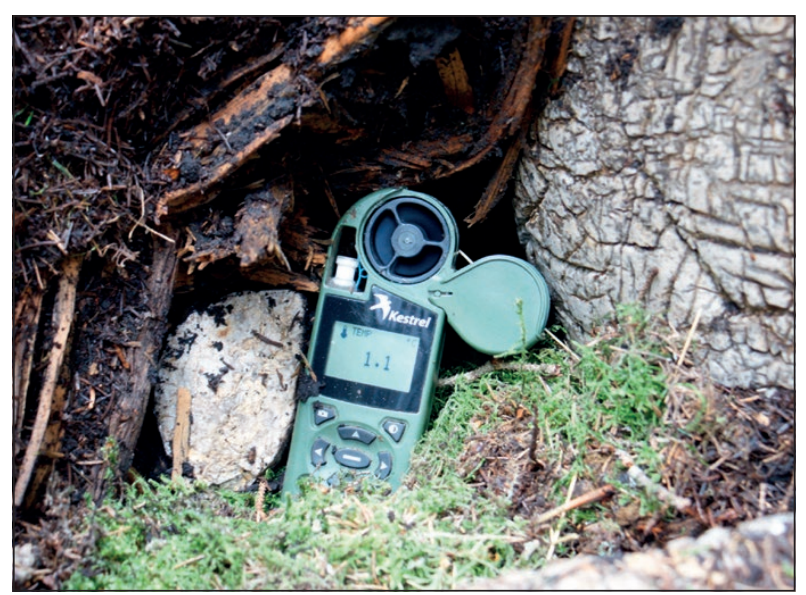

Figure 5: Measurement of airflow velocity in dwarf pine site in the suthern depression (point JK).

it was between 18 and $22^{\circ} \mathrm{C}$. At ground level between the vents the air temperature was around $10^{\circ} \mathrm{C}$.

In the southern doline I measured the temperature at eight powerful vents, although there is a draft between the rocks almost everywhere. There is also a draft on the slopes where there is no more moraine or rubble on the ground. These are vents in limestone pavements. In the lower section of the slope, in the summer I measured the temperatures of air blowing out of the vents at between 0.7 and $2^{\circ} \mathrm{C}$, and in the upper section, where I took measurements at two vents, the temperatures were 1.5 and $3.5^{\circ} \mathrm{C}$. At all eight vents the air speed from the openings was between 0.5 and $2.5 \mathrm{~ms}^{-1}$, while the temperatures measured $0.5 \mathrm{~m}$ from the ground were from $5^{\circ} \mathrm{C}$ to $6^{\circ} \mathrm{C}$, and at a height of $2.5 \mathrm{~m}$ they were $18^{\circ} \mathrm{C}$ to $24^{\circ} \mathrm{C}$. I estimated that in this section of Smrekova draga the outflow from the ground was around $10 \mathrm{~m}^{3} \mathrm{~s}^{-1}$.

In winter the direction of the draft in the vents is reversed. In winter I did not observe the vents, but I conclude the reversal from the temperature recorded by the logger placed in the vent at a depth of half a metre. When the outside temperature drops, it also recorded a lower temperature in the vent; the lowest recorded temperature was $-26^{\circ} \mathrm{C}$. This points to a powerful circulation, since at a depth of $0.5 \mathrm{~m}$ below the surface and under the blanket of snow the temperature would otherwise not be so low. A few metres away I placed another logger which measured the air temperature beneath the snow. This was between $0^{\circ} \mathrm{C}$ and $2^{\circ} \mathrm{C}$ even when the outside temperature was well below freezing.

\section{DOLINES}

I measured the temperature at six dolines between Smrekova draga and the shaft of Suho brezno, which lies west of Paradana. The selected dolines are funnelshaped, between 20 and $40 \mathrm{~m}$ deep and at the perimeter from 100 to $200 \mathrm{~m}$ wide. The dolines have living rock slopes, with their floors covered in boulders overgrown with moss, while higher up grow rhododendrons, bushes and dwarf willows. The inversion layer is just a few metres thick.

At the bottom of all the dolines are vents from which cold air was blowing between the rocks. In some dolines cold air also flowed out on the slopes. At doline $\mathbf{C}$ it flowed out from an elongated groove in the slope, and at doline $\mathbf{D}$ also from a shallow depression in the slope on the upper perimeter of the doline.

In all the dolines, on the bottom around the vents the rocks were bare or covered in thick moss, and a metre or two above the bottom there were rhododendrons and also some shrubs. The vegetation inversion in these dolines reaches up to around $4 \mathrm{~m}$ above the bottom. Yet since the vents are on the slope, beneath them is a narrow band of ground where the rocks are covered in rough humus overgrown with thick moss and blueberries. This vegetation indicates a flow of cold air originating from the ground and running down the slope, and thereby cre-

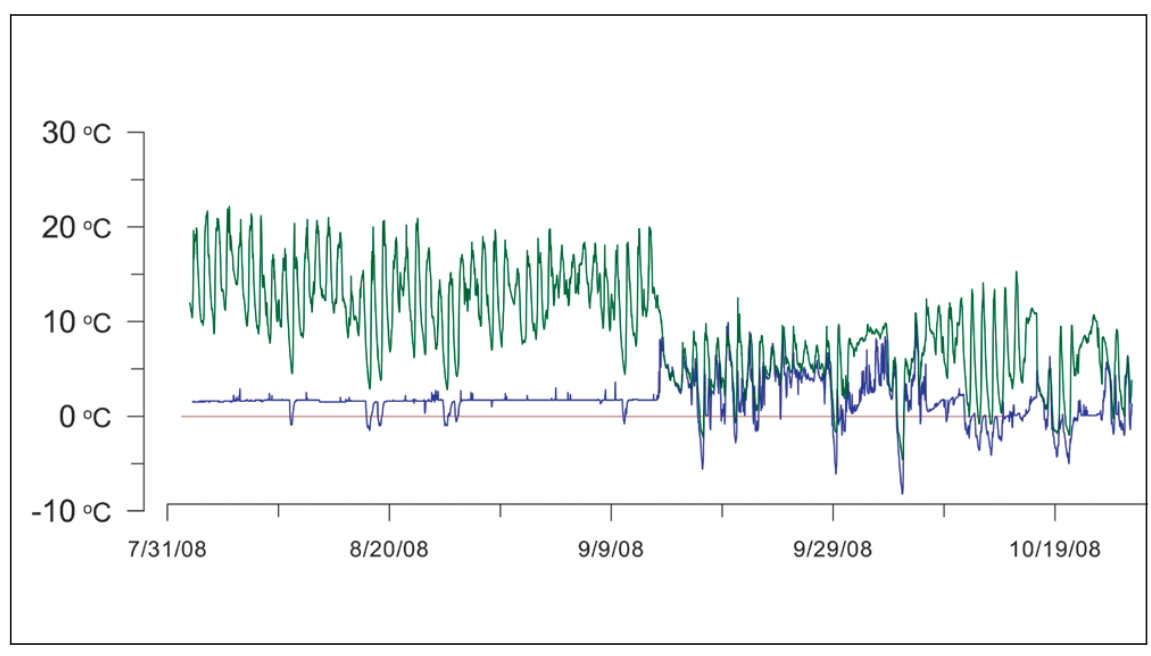

Figure 6: Air temperature in a vent in the southern doline of Smrekova draga (blue) and air temperature at the bottom of Smrekova draga, where there are no vents (green). The stable low temperature of the vent air in the first part of the graph shows that just under the surface the ground is still frozen. The daily variations, which are very pronounced in the surface temperatures, have no effect on it. When the outside temperature falls below around $5^{\circ} \mathrm{C}$, the direction of subterranean air movement reverses and the vent starts sucking in cold air. Occasional rises in temperature in the vent are probably due to warmth brought into the subterranean areas by rainwater. 
ating in the warm part of the year a permanent thermal anomaly.

The temperature of the air blowing out of the ground at all six observed points in the summer of 2012 was between 0.7 and $2.4^{\circ} \mathrm{C}$. The air moved at speeds up to 0.5 $\mathrm{ms}^{-1}$. The concentration of $\mathrm{CO}_{2}$ in the air blown out was between 460 and $550 \mathrm{ppM}$. Since there was no scree on the slopes of the observed dolines, there is no doubt that the air originates from the karstic massif. This is demonstrated by the high level of $\mathrm{CO}_{2}$.

Close to Belo brezno shaft I also measured the temperature at the bottom of the doline, in which there are no ground vents. There the temperature was always around $10^{\circ} \mathrm{C}$ higher, between 12 and $15^{\circ} \mathrm{C}$, and the concentration of $\mathrm{CO}_{2}$ was markedly lower, at around $370 \mathrm{ppM}$, like in the atmosphere.

The cave origin of the air in the vents, with its stable temperature, is also indicated by the measurements in doline C. Strong daily variations with pronounced nocturnal inversion, which is probably intensified by the flow of cold air from the depths, are shown by the air temperature measured $2.5 \mathrm{~m}$ above the ground. The air at a height of $0.5 \mathrm{~m}$ showed quite evenly low temperatures, but with gradual warming towards the end of summer. In the doline there was ice on the bottom between the rocks even in the middle of July. The temperature of the air from the vent remained stable in the summer months, at around $1.5^{\circ} \mathrm{C}$, even when the ice between the rocks on the surface had melted. This low temperature proves the existence of ice and permafrost below the surface thawed layer of ground.

I also measured the temperatures in the cave by the road above Smrekova draga (G) at an altitude of $1,238 \mathrm{~m}$. The entrance to the cave opened onto a cutting for the road. Behind the entrance, which we had to widen, is a $7 \mathrm{~m}$ long tunnel in the rock, which narrows at the end
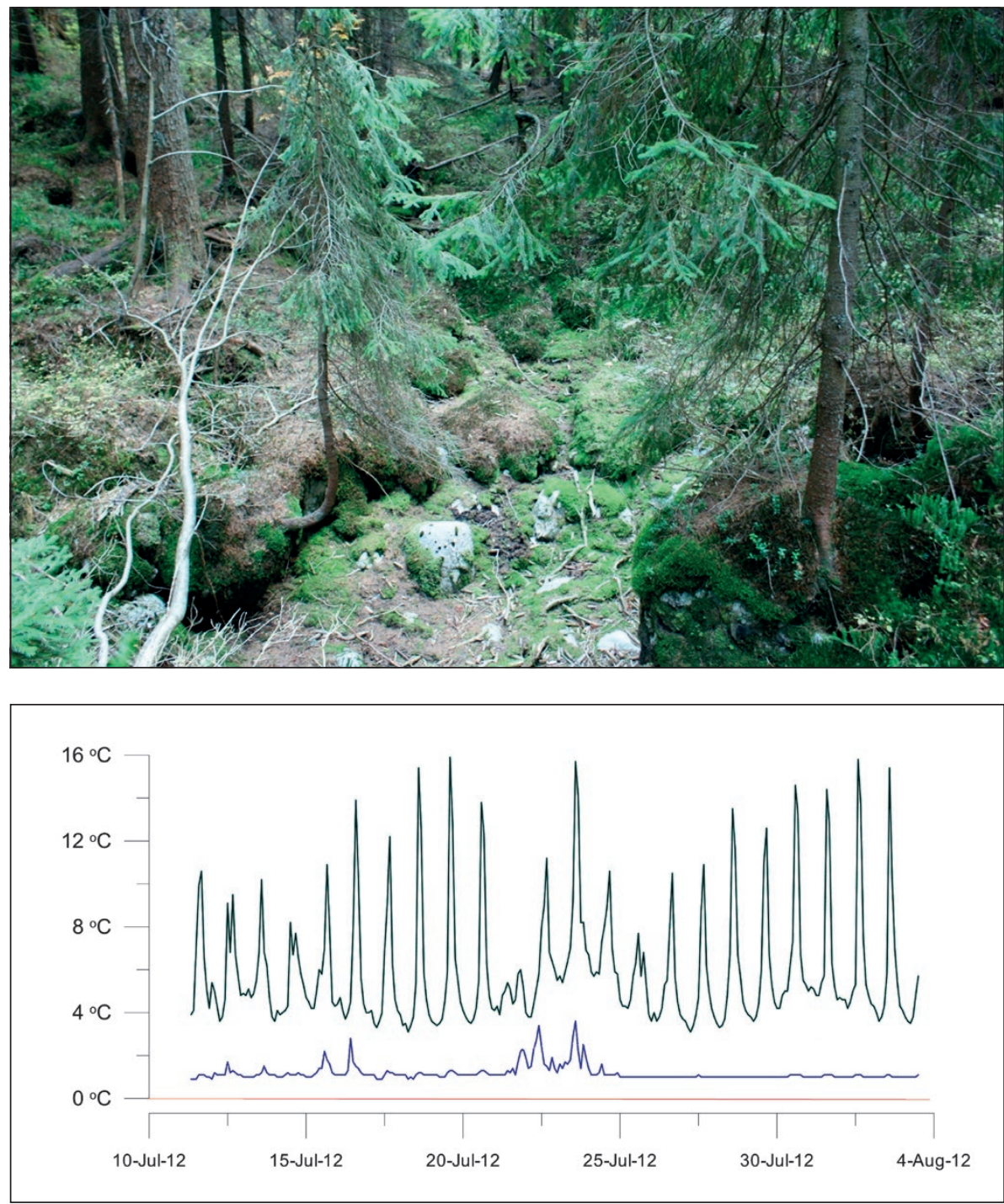

Figure 7: Bottom of a doline. Cold air flows in between the rocks during the summer.

Figure 8: Temperature range in doline $C$ at the end of the summer of 2012. A difference was observed between the daily range of temperatures at a height of $2.5 \mathrm{~m}$ from the ground (green) and the stable temperatures of the air flowing out between the rocks at the bottom of the doline (blue). The stable and low temperature of the vent indicates the existence of permafrost. Occasional rises in the temperature of the air in the vent are probably due to rainwater. 
into several impassable gaps from which a strong breeze blows. In the summer of 2012 a constant flow of air was blowing from the cave at a speed of up to $1 \mathrm{~ms}^{-1}$ and with a temperature of around $4.5^{\circ} \mathrm{C}$ and $480 \mathrm{ppM} \mathrm{CO}_{2}$. This temperature was constant over the whole summer, and undoubtedly indicates the air temperature in the Golak cave system.

\section{DISCUSSION}

I compared the temperatures taken with data on the temperatures stated for the area of Smrekova draga by Zupančič (1980). The coldest month is January $\left(-4^{\circ} \mathrm{C}\right)$, and the hottest July $\left(14^{\circ} \mathrm{C}\right)$, while the annual rainfall is around $2,700 \mathrm{~mm}$. For four months the average temperature is below $0^{\circ} \mathrm{C}$. During this period around $800 \mathrm{~mm}$ of meteoric water falls. The average annual temperature at an altitude of around $1,200 \mathrm{~m}$ is $4-5^{\circ} \mathrm{C}$ (Zupančič
1980). The average temperature, as expected, matches the air temperature (Badino, 1995) we measured at a depth of between 650 and $680 \mathrm{~m}$ (in winter $4.4^{\circ} \mathrm{C}$, in summer $3.9^{\circ} \mathrm{C}$ ) at Paradana and the temperatures in the cave by the road above Smrekova draga.

Based on measurements of the annual air temperature range, Paradana responds in accordance with the theory or observations in other karstic massifs (Badino,

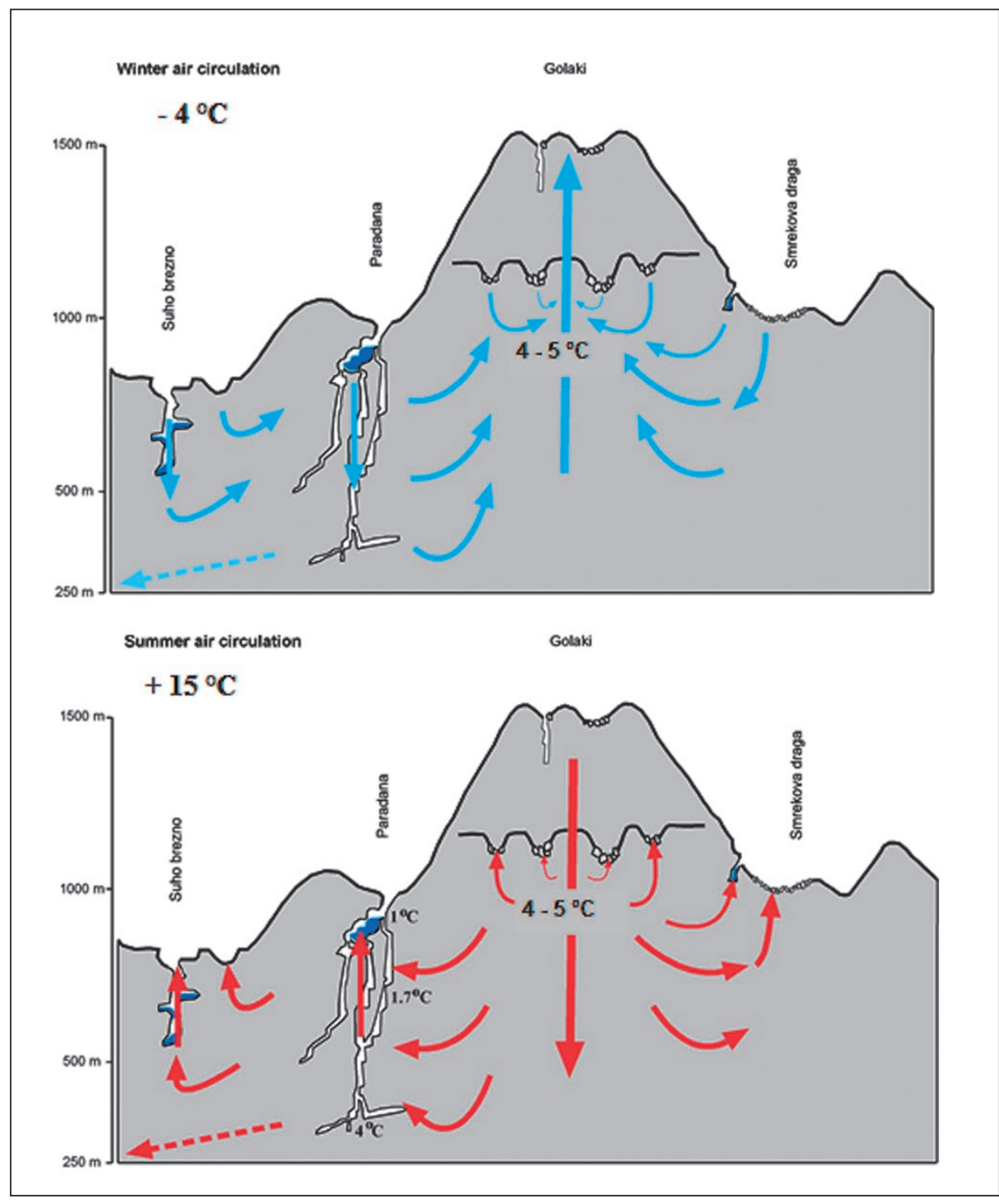

Figure 9: Winter and summer air circulation in the central Golak ridge. The air circulation in Paradana and Suho brezno, two ice caves, is known. In all places where the massif sucks in air in winter, and then in summer blows it out from caves or between rocks, there are pronounced occurrences of thermal and vegetation inversion. In these places, like in the three accessible ice caves, permafrost is maintained in the deep interior. 
1995). In the cave at greater depths the air temperature is the same as the annual average outside temperature. The direction of the air movement and the seasonal reversal of air movement also accord with this theory at Paradana. In the cold half of the year this causes the rock in the eastern part of the cave, due to forcible advection created by the cave system, to cool below $0^{\circ} \mathrm{C}$, thereby making it possible for a subterranean glacier to form from the percolating water. The movement of air in the system is reversed when the outside temperature rises above the average annual temperature, or above the temperature of the cave system. At that time a downward current of air forms in the Golak range, which rises above Paradana. The air flows into the lower sections of Paradana, then moves upwards through the shafts and flows out past the subterranean glacier. In its transit across the ice the air cools. The cooled air then maintains a pool of cold air in the hollow in front of the cave. This depends entirely on the advection of cold air from the cave system.

The cave origin of the inversion layer of air is also indicated by the high concentration of $\mathrm{CO}_{2}$, since the cave air has a much higher level of $\mathrm{CO}_{2}$ than the outside air.

Another important fact based on the observations at Paradana is that the air from the interior of the massif starts to cool when it arrives at the sub-cooled entrance to the cave, until the temperature above the ice settles at around $1^{\circ} \mathrm{C}$. This cold air then maintains a thermal inversion in the entrance doline at the cave. It is significant that throughout the period of thawing the temperature does not change; clearly it stabilises due to the consumption of latent heat necessary to melt the ice.

If we compare this fact with the vents in the dolines or the vents in Smrekova draga, we can see that this involves the same phenomenon, except that in the case of the vents in the dolines and in Smrekova draga the entrances to the cave are buried. Yet since air blows out of the holes between the rocks from the underlying caves at a temperature of around $1^{\circ} \mathrm{C}$, despite the fact that further inside the temperature in the caves is much higher, this means that there is highly cooled rock and permanent ice beneath the vents. In this way we can also explain why the ground above them is often frozen even in August, and why snow lies in them for a long time. This in turn helps us understand the pronounced occurrence of vegetation inversion and its distribution. This is tied to the existence of cave vents and not to the position or aspect within the doline.

Ice caves are a particular type of permafrost, where usually we understand this phenomenon being limited just to cave ice and not the cave itself. The observations and measurements I conducted indicate that permanently frozen ground also appears where the karstic cave system enables similar air circulation. In these places areas of surface permafrost appear. In Trnovski gozd below the Golak mountains there is permafrost at an altitude of around $1,100 \mathrm{~m}$.

Since both forms in which the permafrost appears are tied to air circulation in the karstic cave system, this form of appearance could be called karstic permafrost.

\section{ACKNOWLEDGEMENTS}

This research was conducted as part of research programme P6-0119-0618 and P0-0119 (Karst Research) and the projects J6-3035-0618-01 (Creation and Development of Karst Caves) and J6-6345-0618-04 (Develop- ment and Functioning of Caves in Various Speleological Frameworks). I would also like to thank Marko Erker, member of the Logatec Cave Society, for placing thermometers at Paradana. 


\section{REFERENCES}

Badino, G. 1995: Fisica del clima sotterraneo. - Istituto italiano di speleologia, pp.136, Bologna.

Balch E.S., 1900: Glacières or Freezing Cavernes.-Allen, Lane \& Scott, Philadelphia, pp. 337, New York.

Beck, G. 1906: Die Umkerhrung der Pflanzregionen in den Dolinen des Karstes.-Sitzungsb. Akad. Wiss. Wien, math.-nat. Kl., 115, 1-20.

Delaloye, R., Reynard, E., Lambiel, C., Marescot, L.,Monnet, R. 2003: Thermal anomaly in a cold scree slope (Creux-du-Van, Switzerland).- In: Philips, M., Springman, S.M. \& L.U. Arenson (eds.) Proceedings of the 8th International Conference on Permafrost, A.A. Balkema,175-180, Zurich.

Erker, M., 2014: Nova odkritja v Paradani.- Jamar, 6/1, 21.

Ford, D.C. \& P.W. Williams, 1989: Karst Geomorphology and Hydrology.- Academic Division of Unwin Hyman Ltd, pp. 601, London.

Luetscher, M., 2005: Process in ice caves and their significance for paleoenvironmental reconstructions.$\mathrm{PhD}$ thesis, Swiss Institute for Speleology and Karst Studies (SISKA), La Chaux-de-Fonds, pp. 220.

Habič, P., 1968: Kraški svet med Idrijco in Vipavo : prispevek $k$ poznavanju razvoja kraškega reliefa.- Dela, Slovenska akademija znanosti in umetnosti, 21, pp. 243, Ljubljana.

Fugger, E., 1894: Eishöhlen und windröhren.-Mitheilungen der k.k. geographischen in Wien, XXXVII. Band, 97-134.

Gams, I., 1972: Prispevek k mikroklimatologiji vrtač in kraških polj.- Geografski zbornik, 13, 5-79.

Harris, S.A., 1979: Ice caves and permafrost zones in Southwest Alberta, Erdkunde, 33, 61-70. http:// dx.doi.org/10.3112/erdkunde.1979.01.07

Hribar, F., 1960. Temperatur und Vegetationsumkehrungen in Trnovski gozd.- In: Popović, V. M. (ed.) 6ème Congrès International de Météorologie Alpine, Bled, Yougoslavie, 14.-16. septembre 1960, Beograd, Hidrometeorološki institut SFRJ, 312-344.

Kunaver, P., 1949: Podzemski ledeniki. Proteus 12, p. 13. Kraus, F., 1894: Höhlenkunde. Wege und Zweck der Erforschung unterirdischer Räume.- C.Gerold's Sohn, pp. 308, Wien.

Maire, R., 1990: La Haute Montagne Calcaire.- Presses Universitaires de Bordeaux, pp.731, Bordeaux. https://doi.org/10.4000/books.pub.11090
Martinčič, A., 1977: Prispevek $k$ poznavanju ekologije mrazišč v Sloveniji.- Razprave SAZU 20 (2), pp. 91, Ljubljana.

Martinčič, A., 1998: Smrekova draga.- In: M. Javornik, D.Voglar \& A. Dermastia (eds.) Enciklopedija Slovenije, zv. 12 n-Sz, pp. 90-91, Ljubljana.

Michler, I., 1950: Velika in Mala ledena jama v Paradani.Proteus, 12, p. 7.

Mihevc, A. \& I. Gams, 1979: Nova odkritja v Veliki Ledenici.- Naše jame, 20, 7-21.

Mihevc, A., 1993: Ledene in snežne jame.-Geografski obzornik, 4, 32-35.

Mihevc, A., 2015: The influence of caves on the climate of the karst surface and karst permafrost.- In Čolak, I. (ed.) Zbornik radova. Mostar: Sveučilište, 117-129.

Morard, S., Delaloye, R. \& J. Dorthe, 2008: Seasonal thermal regime of a mid-latitude ventilated debris accumulation.- In: D. L. Kane \& M. H. Hinkel (eds.) Proceedings of the Ninth International Conference on Permafrost, July 2008, Fairbanks, 1233-1238.

Morard, S., 2011: Effets de la circulation d'air par effet de cheminée dans l'évolution du régime thermique des éboulis froids de basse et moyenne altitude.- PhD thesis. Département de Géosciences - Géographie,Université de Fribourg, pp. 220.

Moser, L.C., 1889: Die Eishöhlen des Tarnowaner und Birnbaumer Waldgebirges.-Zeitschrift des Deutschen und Oesterreichischen Alpenvereins, 20, 351-368.

Mulec, J., Oarga-Mulec, A., Holko, L., Pašić, L., Kopitar, A.N., Eleršek, T. \& A. Mihevc, 2021: Microbiota entrapped in recently-formed ice: Paradana Ice Cave, Slovenia.-Sci Rep 11, https://doi.org/10.1038/ s41598-021-81528-6.

Nagode, M., 2002: Najnovejše raziskave Velike ledenice v Paradani in jam ob njej.- Naše jame 44, 98-113.

Melik, A., 1960: Slovensko Primorje. Slovenija, Knj. 4.Slovenska Matica, pp. 547, Ljubljana.

Perşoiu, A. \& S-E Lauritzen (eds.), 2018: Ice caves.- Elsevier, pp. 752, Netherlands.

Zupančič, M, 1980: Smrekovi gozdovi v mraziščih dinarskega gorstva Slovenije.- Dela, Slovenska akademija znanosti in umetnosti, 24, pp. 162, Ljubljana. 